\title{
The Effects of Damage to the Outer Race Bearing on the Efficiency of the Induction Motor Using Fast Fourier Transform (FFT) Method
}

\section{Efek Kerusakan Outer Race Bearing Terhadap Efisiensi Motor Induksi Menggunakan Metode Fast Fourier Transform (FFT)}

\author{
Sulaiman Isfar ${ }^{\text {l) }}$, Iradiratu Diah Prahmana Karyatanti ${ }^{2}$, Belly Yan Dewantara ${ }^{3)}$ \\ ${ }^{1,2,3)}$ Departement Electrical Engineering, Hang Tuah University Surabaya, Indonesia \\ 1) sulaimanisfar@gmail.com, ${ }^{2}$ iradiratu@ @angtuah.ac.id, ${ }^{3)}$ bellyyandewantara@hangtuah.ac.id
}

\begin{abstract}
Bearing is an induction motor component that helps the rotor to move freely, in industrial applications it is important to maintain bearing performance in induction motors. In its use, bearing damage is one of the biggest types of damage that is often found in induction motors. Bearing damage can lead to increased vibration, increased noise, increased working temperature, and decreased efficiency. Efficiency reduction can be used as information on the condition of the motor so that this information can be used to detect damage before more serious damage occurs. This research discusses the stator current analysis method and the efficiency of damage to the motor through two harmonic amplitude ratios equipped with the fast Fourier transform (FFT) algorithm in detecting damage to the outer race bearing. It is hoped that this efficiency can be used as an evaluation of the extent to which motor energy waste occurs before more severe damage. The efficiency results on the damage to the outer race bearing using the FFT method get the highest efficiency value of 1.47 and the lowest value of 0.66 .
\end{abstract}

Keywords: MCSA; Outer Race Bearing; Fast Fourier Transform (FFT); Induction Motor; Efficiency.

\begin{abstract}
Abstrak-.Bearing merupakan komponen motor induksi yang membantu rotor agar dapat bergerak secara bebas, dalam aplikasi industri penting untuk menjaga performa bearing pada motor induksi. Dalam pemakaiannya kerusakan bearing menjadi salah satu jenis kerusakan terbesar yang sering ditemui pada motor induksi. Kerusakan bearing dapat menyebabkan terjadinya peningkatan getaran, peningkatan kebisingan, peningkatan suhu kerja, serta penurunan efisiensi. Penurunan effisiensi dapat digunakan sebagai informasi kondisi motor sehingga informasi ini dapat digunakan untuk deteksi kerusakan sebelum terjadi kerusakan yang lebih parah. Pada penelitian ini membahas mengenai metode analisis arus stator dan effisiensi kerusakan pada motor melalui dua rasio amplitude harmonic yang dilengkapi dengan algoritma fast fourier transform (FFT) dalam mendeteksi kerusakan outer race bearing. Diharapakan dengan adanya efisiensi tersebut, dapat digunakan sebagai evaluasi sejauh mana pemborosan energi motor terjadi sebelum kerusakan yang lebih parah. Hasil effisiensi pada kerusakan outer race bearing menggunakan metode FFT mendapatkan nilai effisiensi tertinggi sebesar 1,47 dan nilai terendah sebesar 0,66.
\end{abstract}

Kata kunci: MCSA; Outer Race Bearing; Fast Fourier Transform (FFT); Motor Induksi; Effisiensi. 


\section{PENDAHULUAN}

Kerusakan bearing merupakan salah satu jenis kerusakan terbesar yang sering ditemui pada motor induksi. Kerusakan bearing bedasarkan lokasinya dapat dikategorikan sebagai kerusakan inner-race dan outerrace. Penyebab utama dari kerusakan bearing adalah tercemarnya pelumas, hilangnya minyak pelumas, beban yang berlebih dan panas yang berlebih. Bearing merupakan komponen motor induksi yang membantu rotor agar dapat bergerak secara bebas. Kerusakan bearing dapat menyebabkan terjadinya vibrasi, noise (bising), peningkatan suhu kerja, dan timbulnya bunga api yang dapat menyebabkan kerusakan pada bagian motor induksi yang lain [6].

Gangguan pada motor induksi dapat dideteksi pada saat permulaan dengan cara menganalisis gelombang arusnya yang disebut MCSA (Motor Current Signature Analysis). Salah satu teknik diagnosa yang digunakan adalah FFT (Fast Fourier Transfrom) [10].

Effisiensi sebuah mesin adalah suatu ukuran seberapa baik mesin dapat mengubah energy masukan listrik ke energy keluaran mekanik [9]. Penurunan effisiensi dapat digunakan sebagai informasi kondisi motor, sehingga informasi ini dapat digunakan untuk deteksi kerusakan sebelum terjadi kerusakan yang lebih parah dan kerugian energy motor. Untuk mendapatkan effisiensi kerusakan pada motor menurut Alexandru lonel dapat di tentukan melalui rasio dua amplitudo harmonic [2].

Penelitian ini akan memantau dan menganalisa penurunan efisiensi motor dengan melakukan beberapa eksperimen berupa rekonstruksi kerusakan bearing serta pemberian beban mekanis yang bervariasi mulai dari tanpa beban, beban minimum sampai beban maksimum untuk mengetahui performa dari metode deteksi kerusakan outer race bearing.

[Figure 1 about here.]

\section{METODE PENELITIAN}

Pada diagram blok penelitian ini sumber ac 3 fasa digunakan untuk mengoperasikan motor induksi. Pada motor induksi diberi beberapa percobaan yang pertama motor dalam keadaan normal dan yang kedua motor dalam keadaan bearing rusak, kemudian diberi 2 beban berupa beban elektris dan mekanik. Dalam penelitian ini berfokus pada deteksi kerusakan dengan motode MCSA ( motor current signature analiysis) dimana metode ini memerlukan sinyal arus untuk dianalisis, sinyal arus tersebut didapat dari instrument NI DAQ yang dipasang pada bagian stator motor.

NI DAQ digunakan sebagai media yang mengubah sinyal arus stator menjadi sekumpulan data secara digital dan melakukan akuisisi data untuk keperluan analisis. kemudian akan dikirim ke komputer untuk menampilkan dan mengkonversi data sinyal arus stator yang telah diakuisisi dengan menggunakan software LabVIEW. Beberapa peralatan tersebut dirancang sedemikian rupa sehingga konfigurasinya dapat dilihat pada Gambar 1

\subsection{Spesifikasi \\ Pada penelitian ini spesifikasi motor dan bearing yang digunakan adalah :}

[Table 1 about here.]

[Table 2 about here.]

\subsection{Rekontruksi kerusakan bearing}

Pada penelitian ini rekontruksi kerusakan bearing dilakukan dengan memberikan kecacatan pada bagian outer race bearing, hal ini dapat terlihat pada gambar 2

[Figure 2 about here.]

\subsection{Proses Perhitungan}

a. Fast fourier Transfrom (FFT)

Fast Fourier Transform (FFT) merupakan suatu metode perhitungan cepat dari Discrete Fourier Transform (DFT) atau dengan kata lain FFT merupakan pengembangan dari DFT. DFT merupakan suatu metode perhitungan yang mengubah sinyal dari domain waktu ke domain frekuensi. Biasanya DFT digunakan untuk keperluan analisis spektrum dalam domain frekuensi [3].

\section{b. Letak prediksi frekuensi}

Letak prediksi frekuensi digunakan sebagai input mencari nilai amplitude pada figure FFT seperti di bawah ini:

$f_{o}=0.4 . N . f_{r}$

$f_{p}=\left[f_{s} \pm k f_{o}\right]$

Dimana:

$f_{o}=$ frekuensi yang menunjukkan kesalahan outer race

$f_{p}=$ Frekuensi Prediksi Kerusakan Bearing

$f_{s}=$ frekuensi dasar catu daya $(50 \mathrm{~Hz})$

$k=$ konstanta $( \pm 1$ sampai \pm 10$)$

$N=$ jumlah ball bearing

\section{c. Effisiensi}

Penurunan effisiensi dapat digunakan sebagai informasi kondisi motor sehingga informasi ini dapat digunakan untuk deteksi kerusakan sebelum terjadi kerusakan yang lebih parah dan kerugian pada energy motor. Untuk mendapatkan effisiensi kerusakan pada motor dapat di tentukan rasio dua amplitudo harmonic dengan menggunakan rumus [2]:

Effisiensi fault detection $=\frac{F E}{F H}$.......(3)

Dimana :

$\mathrm{FE}=$ Value of harmonic amplitude in fault state 


\section{$\mathrm{FH}=$ Value of harmonic amplitude in healthy state}

\subsection{Hasil Dan pembahasan}

Hasil dari effisiensi kerusakan outer race bearing pada penielitian ini didapat pada perhitungan dan pengujian pada motor normal dan motor mengalami kerusakan dengan menggunakan metode fast fourier transform. Hasil figure FFT pada gambar 3 Sampai gambar 5, Dimana gambar tersebut merupakan hasil bearing normal dan kerusakan 1 lubang 2mm, 2 lubang $2 \mathrm{~mm}$ dan 3 lubang $2 \mathrm{~mm}$ dengan bebab $0 \%$ dan beban $75 \%$.

[Figure 3 about here.]

[Figure 4 about here.]

[Figure 5 about here.]

Gambar diatas merupakan hasil figure FFT dimana sumbu x merupakan frekuensi / letak prediksi spectrum yang telah dihitung dan sumbu y merupakan nilai amplitude yang akan diambil dan dianalisis effisiensi kerusakan pada motor. Untuk mendapatkan effisiensi kerusakan pada motor dapat di tentukan melalui rasio dua amplitudo harmonic, hal lebih lanjut akan di jelaskan pada tabel dibawah ini.

[Figure 6 about here.]

[Table 3 about here.]

Tabel 3 diatas pada beban 0\% dikeruskan 1 lubang $2 \mathrm{~mm}$ mendapatkan nilai effisiensi tertinggi sebesar 1,30 dan terendah 0,84 , pada kerusakan 2 lubang $2 \mathrm{~mm}$ nilai tertinggi sebesar 1,47 dan terendah sebesar 0,83 dan di kerusakan 3 lubang $2 \mathrm{~mm}$ nilai tertinggi sebesar 1,17 dan terendah sebesar 0,83 .

\section{[Table 4 about here.]}

Tabel 4 diatas pada beban $75 \%$ dikeruskan 1 lubang $2 \mathrm{~mm}$ mendapatkan nilai effisiensi tertinggi sebesar 1,31 dan terendah 0,79 , pada kerusakan 2 lubang $2 \mathrm{~mm}$ nilai tertinggi sebesar 1,07 dan terendah sebesar 0,66 dan di kerusakan 3 lubang $2 \mathrm{~mm}$ nilai tertinggi sebesar 1,33 dan terendah sebesar 0,86.Sehingga dapat disimpulkan padasemua kondisi mendapatkan nilai effisiensi tertinggi sebesar 1,47 dan nilai terendah sebesar 0,66.

\section{KESIMPULAN}

1. Keberhasilan deteksi kerusakan outer race bearing menggunakan metode FFT dengan kerusakan yang berbeda dan beban yang bervariasi maka mendapatkan presentase sekitar $25-75 \%$.
2. Effisiensi pada kondisi kerusakan outer race bearing dengan variasi beban :

a) 1 lubang $2 \mathrm{~mm}$ nilai tertinggi 1,31 dan nilai terendah 0,79

b) 2 lubang $2 \mathrm{~mm}$ nilai tertinggi 1,47 dan nilai terendah 0,66

c) 3 lubang $2 \mathrm{~mm}$ nilai tertinggi 1,33 dan nilai terendah 0,73

3. Tingkat pembebanan yang diberikan pada motor induksi dapat membantu mempermudah menentukan letak prediksi frekuensi kerusakan outer race bearing. berdasarkan hasil pengujian dan analisis effisiensi sebagai berikut:

a) Untuk kondisi beban $0 \%$ mendapatkan nilai effisiensi pada nilai tertinggi 1,47 dan nilai terendah sebesar 0,83

b) Untuk kondisi beban $75 \%$ mendapatkan nilai effisiensi pada nilai tertinggi 1,33 dan nilai terendah sebesar 0,66

4. Effisiensi dapat digunakan sebagai informasi kondisi motor seberapa besar kerugian pada energy motor dengan cara menganalisa rasio dua ampliudo harmonic pada spectrum arus, pada eksperimen penelitian ini didapat nilai effisiensi terrtinggi sebesar 1,47 dan nilai terendah sebesar 0,66.

\section{REFERENSI}

[1] Asfani, D. A., Soedibyo, S., Negara, I. M. Y., Fahmi, D., Septiawan, M. E., Wahyudi, M., \& Rifma, N. I. (2017). Design of Motor Current Signature Analyses (MCSA) Based on LabVIEW for Online Detection of Induction Motor Faults. JAREE (Journal on Advanced Research in Electrical Engineering), 1(2), 27-34. https://doi.org/10.12962/j25796216.v1.i2.20.

[2] Constantin, A. I., \& Fireţeanu, V. (2015). Efficiency in the detection of three important faults in induction motors through external magnetic field. 2015 9th International Symposium on Advanced Topics in Electrical Engineering, ATEE 2015, 430-435. https://doi.org/10.1109/ATEE.2015.7133843

[3] DPK, I., Dewantara, B. Y., \& Janudin, A. M. (2019). Deteksi Kerusakan Inner Race Bearing Menggunakan Motor Current Signature Analysis Berbasis Fast Fourier Transform. Jurnal Teknik Elektro Dan Komputer TRIAC, 6(1), 24-25. https://doi.org/10.21107/triac.v6i1.5145.

[4] Fireteanu, V., Leconte, V., \& Constantin, A. I. (2015). Influence of the magnetic steel frame on the efficiency of short-circuit faults detection in induction motors through harmonics of the neighboring magnetic field. 2015 9th International 
Symposium on Advanced Topics in Electrical Engineering, ATEE 2015, 398-403. https://doi.org/10.1109/ATEE.2015.7133836.

[5] Frosini, L., \& Bassi, E. (2010). Stator current and motor efficiency as indicators for different types of bearing faults in induction motors. IEEE Transactions on Industrial Electronics. https://doi.org/10.1109/TIE.2009.2026770.

[6] Haddad, R. Z., Lopez, C. A., Pons-Llinares, J., Antonino-Daviu, J., \& Strangas, E. G. (2015). Outer race bearing fault detection in induction machines using stator current signals. Proceeding - 2015 IEEE International Conference on Industrial Informatics, INDIN 2015, 801-808. https://doi.org/10.1109/INDIN.2015.7281839.

[7] Iradiratu Diah, P. K., Dewantara, B. Y., Abduh, M., Sudirman, \& Utomo, W. M. (2019). Healthy monitoring and fault detection outer race bearing in induction motor using stator current. International Journal of Integrated Engineering, 11(3), 181-193. https://doi.org/10.30880/ijie.2019.11.03.019.

[8] Leggate, D., Pankau, J., Schlegel, D. W., Kerkman, R. J., \& Skibinski, G. L. (1999). Reflected waves and their associated current. IEEE Transactions on Industry Applications. https://doi.org/10.1109/ias.1998.732416.

[9] Septianto, F., Widodo, A., Jurusan, M., Mesin, T., Teknik, F., Diponegoro, U.,Diponegoro, U. (2015). Online: http://ejournal-s1.undip.ac.id/index.php/jtm Online: http://ejournal-s1.undip.ac.id/index.php/jtm, 4(4), 397-407.

[10] Thipsuwanporn, V., Numsamran, A., \& Leawsoong, M. (2012). Balance weight fault detection in compressor using FFT algorithm. International Conference on Control, Automation and Systems, 798-802.

Conflict of Interest Statement: The author declares that the research was conducted in the absence of any commercial or financial relationships that could be construed as a potential conflict of interest.

Copyright $\odot 2021$ Author [s]. This is an open access article distributed un- der the terms of the Creative Commons Attribution License (CC BY). The use, distribution or reproduction in other forums is permitted, provided the original author(s) and the copyright owner(s) are credited and that the original publication in this journal is cited, in accordance with accepted academic practice. No use, distribution or reproduction is permitted which does not comply with these terms.

Received: 2021-02-20

Accepted: 2021-03-15

Published: 2021-04-10 


\section{DAFTAR TABEL}

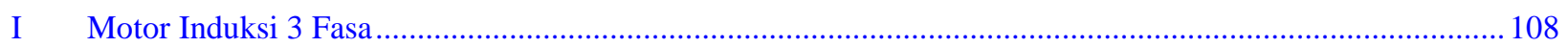

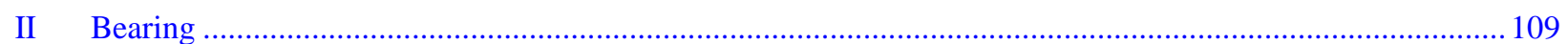

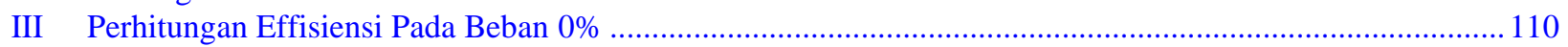

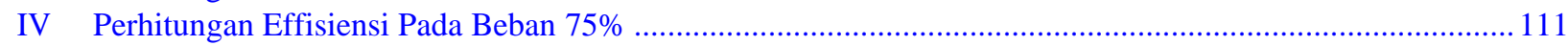


Table I. Motor Induksi 3 Fasa

\begin{tabular}{|l|l|}
\hline Merek & Tatung \\
\hline Tegangan & $220 / 380 \mathrm{~V}$ \\
\hline Daya & $2 \mathrm{HP} / 1,5 \mathrm{Kw}$ \\
\hline Arus & $6,09 / 3,53 \mathrm{~A}$ \\
\hline Frekuensi & $50 \mathrm{z}$ \\
\hline
\end{tabular}


Table II. Bearing

\begin{tabular}{|l|c|}
\hline \multicolumn{1}{|c|}{ Merk } & ASB \\
\hline Type & $6205 \mathrm{ZZ}$ \\
\hline Diameter Dalam (Inner) & $25 \mathrm{~mm}$ \\
\hline Jumlah Bola & $9 \mathrm{Buah}$ \\
\hline Lebar Bearing & $15 \mathrm{~mm}$ \\
\hline Diameter Luar (outer) & $51 \mathrm{~m}$ \\
\hline
\end{tabular}


Table III. Perhitungan Effisiensi Pada Beban 0\%

\begin{tabular}{|c|c|c|c|c|c|c|c|c|c|c|}
\hline \multicolumn{11}{|c|}{ Beban 0\% } \\
\hline \multicolumn{11}{|c|}{ Amplitudo (dB) } \\
\hline & $\begin{array}{l}\text { Kondigi } \\
\text { Normal }\end{array}$ & $\begin{array}{l}\text { Kerusakan } 1 \\
\text { Lubang } 2 \mathrm{~mm}\end{array}$ & $\begin{array}{c}\text { Effisiensi } \\
\text { (FE/FHA l } \\
\text { Lubang } \\
2 \mathrm{~mm}\end{array}$ & Note & $\begin{array}{l}\text { Kerusakan } 2 \\
\text { Lubang } 2 \mathrm{~mm}\end{array}$ & $\begin{array}{c}\text { Effisiensi } \\
\text { (FE/FHA } 2 \\
\text { Lubang } \\
2 \mathrm{~mm} \\
\end{array}$ & Note & $\begin{array}{c}\text { Kerusakan } \\
3 \text { Lubang } \\
2 \mathrm{~mm}\end{array}$ & $\begin{array}{c}\text { Effisiensi } \\
\text { (FE/FH) } \\
3 \text { Lubang } \\
2 \mathrm{~mm} \\
\end{array}$ & Note \\
\hline$f_{0}(k=1)$ & $-48,48$ & $-57,64$ & 1,19 & 1 & $-62,05$ & 1,28 & 1 & $-55,99$ & 1,15 & 1 \\
\hline$f_{2}(k=-1)$ & $-50,05$ & $-47,32$ & 0,95 & 2 & $-41,74$ & 0,83 & 2 & $-41,52$ & 0,83 & 2 \\
\hline$f_{0}(k=2)$ & $-61,79$ & $-55,98$ & 0,91 & 2 & $-64,23$ & 1,04 & 1 & $-61,08$ & 0,99 & 2 \\
\hline$f_{s}(k=-2)$ & $-66,06$ & $-61,27$ & 0,93 & 2 & $-58,17$ & 0,88 & 2 & $-59,65$ & 0,90 & 2 \\
\hline$f_{0}(k=3)$ & $-71,36$ & $-69,44$ & 0,97 & 2 & $-67,46$ & 0,95 & 2 & $-65,04$ & 0,91 & 2 \\
\hline$f_{0}(k=-3)$ & $-65,2$ & $-63,07$ & 0,97 & 2 & $-65,97$ & 1,01 & 1 & $-62,45$ & 0,96 & 2 \\
\hline$f_{0}(k=4)$ & $-69,06$ & $-67,65$ & 0,98 & 2 & $-80,39$ & 1,16 & 1 & $-76,55$ & 1,11 & 1 \\
\hline$f_{5}(k=-4)$ & $-70,88$ & $-73,21$ & 1,03 & 1 & $-72,05$ & 1,02 & 1 & $-67,54$ & 0,95 & 2 \\
\hline$f_{0}(k=5)$ & $-71,02$ & $-68,21$ & 0,96 & 2 & $-74,54$ & 1,05 & 1 & $-74,98$ & 1,06 & 1 \\
\hline$f_{s}(k=-5)$ & $-65,34$ & $-70,77$ & 1,08 & 1 & $-76,08$ & 1,16 & 1 & $-71,75$ & 1,10 & 1 \\
\hline$f_{p}(k=6)$ & $-71,83$ & $-80,3$ & 1,12 & 1 & $-79,12$ & 1,10 & 1 & $-81,38$ & 1,13 & 1 \\
\hline$f_{p}(k=-6)$ & $-74,42$ & $-70,75$ & 0,95 & 2 & $-73,43$ & 0,99 & 2 & $-78,37$ & 1,05 & 1 \\
\hline$f_{p}(k=7)$ & $-66,36$ & $-68,01$ & 1,02 & 1 & $-74,63$ & 1,12 & 1 & $-75,39$ & 1,14 & 1 \\
\hline$f_{p}(k=-7)$ & $-89,23$ & $-74,63$ & 0,84 & 2 & $-80,16$ & 0,90 & 2 & $-74,44$ & 0,83 & 2 \\
\hline$f_{p}(k=8)$ & $-71,33$ & $-76,59$ & 1,07 & 1 & $-86,66$ & 1,21 & 1 & $-83,46$ & 1,17 & 1 \\
\hline$f_{p}(k=-8)$ & $-69,49$ & $-90,2$ & 1,30 & 1 & $-74,94$ & 1,08 & 1 & $-72,23$ & 1,04 & 1 \\
\hline$f_{p}(k=9)$ & $-72,85$ & $-76,86$ & 1,06 & 1 & $-106,9$ & 1,47 & 1 & $-84,24$ & 1,16 & 1 \\
\hline$f_{p}(k=-9)$ & $-75,7$ & $-77,7$ & 1,03 & 1 & $-91,66$ & 1,21 & 1 & $-86,37$ & 1,14 & 1 \\
\hline$f_{p}(k=10)$ & $-74,72$ & $-75,49$ & 1,01 & 1 & $-91,53$ & 1,22 & 1 & $-82,42$ & 1,10 & 1 \\
\hline$f_{p}(k=-10)$ & $-74,37$ & $-79,56$ & 1,07 & 1 & $-87,26$ & 1,17 & 1 & $-82,54$ & 1,11 & 1 \\
\hline
\end{tabular}




\section{$\pi \sqrt{A} \mathbb{T}$ Journal of Electrical and Electronic Engineering-UMSIDA C C 4 - ISSN 2460-9250 (print), ISSN 2540-8658 (online)

Table IV. Perhitungan Effisiensi Pada Beban 75\%

\begin{tabular}{|c|c|c|c|c|c|c|c|c|c|c|}
\hline \multicolumn{11}{|c|}{ Beban $75 \%$} \\
\hline \multicolumn{11}{|c|}{ Amplitudo (dB) } \\
\hline & $\begin{array}{l}\text { Kondisi } \\
\text { Normal }\end{array}$ & $\begin{array}{l}\text { Kerusakan } 1 \\
\text { Lubang } 2 \mathrm{~mm}\end{array}$ & $\begin{array}{l}\text { Effisiensi } \\
\text { (FE/FHDh } 1 \\
\text { Lubang } \\
2 \mathrm{~mm}\end{array}$ & Note & $\begin{array}{l}\text { Kerusakan } 2 \\
\text { Lubang } 2 \mathrm{~mm}\end{array}$ & $\begin{array}{l}\text { Effisiensi } \\
\text { (FE/FHD } 2 \\
\text { Lubang } \\
2 \mathrm{~mm} \\
\end{array}$ & Note & $\begin{array}{c}\text { Kerusakan } \\
3 \text { Lubang } \\
2 \mathrm{~mm}\end{array}$ & $\begin{array}{l}\text { Effisiensi } \\
\text { (FEFH) } \\
3 \text { Lubang } \\
2 \mathrm{~mm} \\
\end{array}$ & Note \\
\hline$f_{0}(k=1)$ & $-50,74$ & $-51,31$ & 1,01 & 1 & $-47,47$ & 0,94 & 2 & $-48,21$ & 0,95 & 2 \\
\hline$f_{n}(k=-1)$ & $-36,98$ & $-36,76$ & 0,99 & 2 & $-24,51$ & 0,66 & 2 & $-48,48$ & 1,31 & 1 \\
\hline$f_{0}(k=2)$ & $-53,23$ & $-69,48$ & 1,31 & 1 & $-53,49$ & 1,00 & 1 & $-55,3$ & 1,04 & 1 \\
\hline$f_{s}(k=-2)$ & $-48,96$ & $-50,75$ & 1,04 & 1 & $-52,61$ & 1,07 & 1 & $-65,3$ & 1,33 & 1 \\
\hline$f_{0}(k=3)$ & $-69,35$ & $-72,88$ & 1,05 & 1 & $-66,21$ & 0,95 & 2 & $-59,96$ & 0,86 & 2 \\
\hline$f_{s}(k=-3)$ & $-78,84$ & $-62,02$ & 0,79 & 2 & $-58,93$ & 0,75 & 2 & $-72,18$ & 0,92 & 2 \\
\hline$f_{0}(k=4)$ & $-62,32$ & $-69,81$ & 1,12 & 1 & $-65,74$ & 1,05 & 1 & $-59,35$ & 0,95 & 2 \\
\hline$f_{2}(k=-4)$ & $-63,62$ & $-70,13$ & 1,10 & 1 & $-66,55$ & 1,05 & 1 & $-66,43$ & 1,04 & 1 \\
\hline$f_{0}(k=5)$ & $-67,94$ & $-63,99$ & 0,94 & 2 & $-64,26$ & 0,95 & 2 & $-58,88$ & 0,87 & 2 \\
\hline$f_{D}(k=-5)$ & $-65,13$ & $-63,45$ & 0,97 & 2 & $-66,72$ & 1,02 & 1 & $-61,51$ & 0,94 & 2 \\
\hline$f_{0}(k=6)$ & $-70,89$ & $-68,42$ & 0,97 & 2 & $-60,14$ & 0,85 & 2 & $-69,9$ & 0,99 & 2 \\
\hline$f_{s}(k=-0)$ & $-63,2$ & $-63,23$ & 1,00 & 1 & $-60,91$ & 0,96 & 2 & $-69,22$ & 1,10 & 1 \\
\hline$f_{0}(k=7)$ & $-72,27$ & $-73,59$ & 1,02 & 1 & $-71,26$ & 0,99 & 2 & $-76,07$ & 1,05 & 1 \\
\hline$f_{5}(k=-7)$ & $-77,07$ & $-62,89$ & 0,82 & 2 & $-63,65$ & 0,83 & 2 & $-72,47$ & 0,94 & 2 \\
\hline$f_{0}(k=8)$ & $-81,8$ & $-78,38$ & 0,96 & 2 & $-71,82$ & 0,88 & 2 & $-76,35$ & 0,93 & 2 \\
\hline$f_{5}(k=-8)$ & $-73,65$ & $-75,18$ & 1,02 & 1 & $-76,89$ & 1,04 & 1 & $-74,15$ & 1,01 & 1 \\
\hline$f_{0}(k=9)$ & $-78,79$ & $-72,7$ & 0,92 & 2 & $-70,93$ & 0,90 & 2 & $-72,25$ & 0,92 & 2 \\
\hline$f_{s}(k=-9)$ & $-79,73$ & $-70,56$ & 0,88 & 2 & $-75,12$ & 0,94 & 2 & $-72,65$ & 0,91 & 2 \\
\hline$f_{n}(k=10)$ & $-78,36$ & $-76,94$ & 0,98 & 2 & $-74,01$ & 0,94 & 2 & $-76,62$ & 0,98 & 2 \\
\hline$f_{0}(k=-10)$ & $-77,94$ & $-75,57$ & 0,97 & 2 & $-72,83$ & 0,93 & 2 & $-74,01$ & 0,95 & 2 \\
\hline
\end{tabular}




\section{DAFTAR GAMBAR}

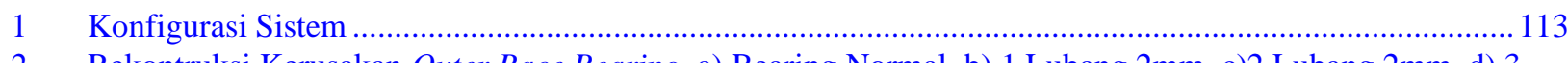

2 Rekontruksi Kerusakan Outer Race Bearing, a) Bearing Normal, b) 1 Lubang 2mm, c)2 Lubang 2mm, d) 3 Lubang $2 \mathrm{~mm}$...

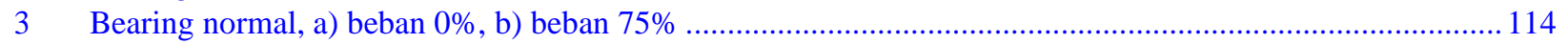

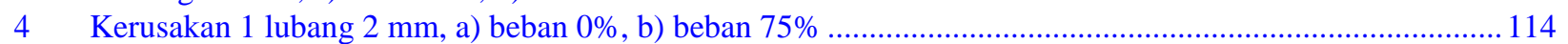

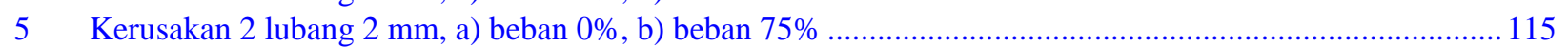

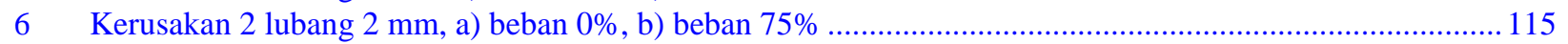




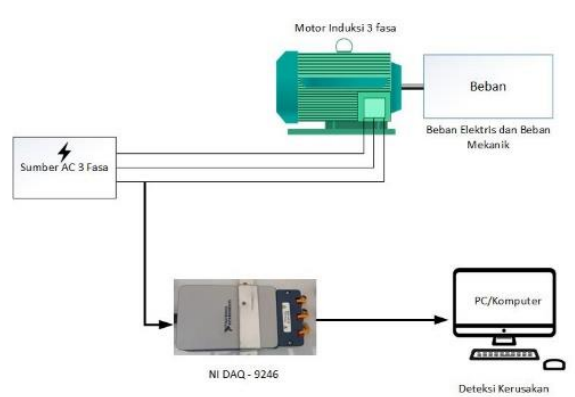

Figure 1. Konfigurasi Sistem

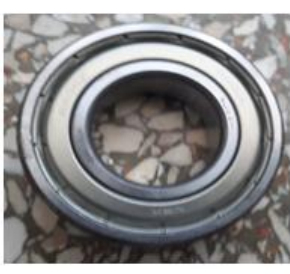

(a)

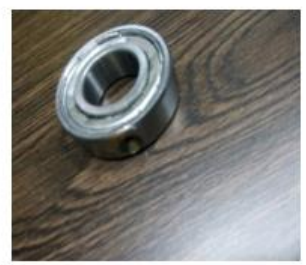

(c)

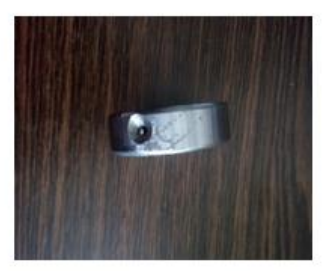

(b)

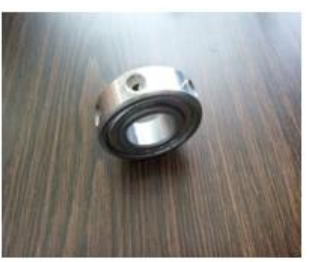

(d)

Figure 2. Rekontruksi Kerusakan Outer Race Bearing, a) Bearing Normal, b) 1 Lubang 2mm, c)2 Lubang 2mm, d) 3 Lubang $2 \mathrm{~mm}$ 


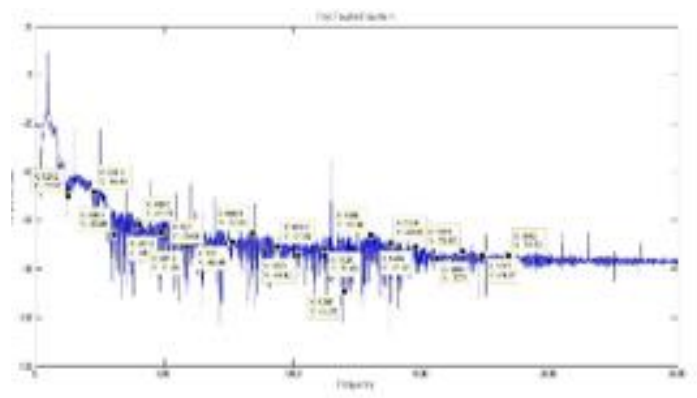

(a)

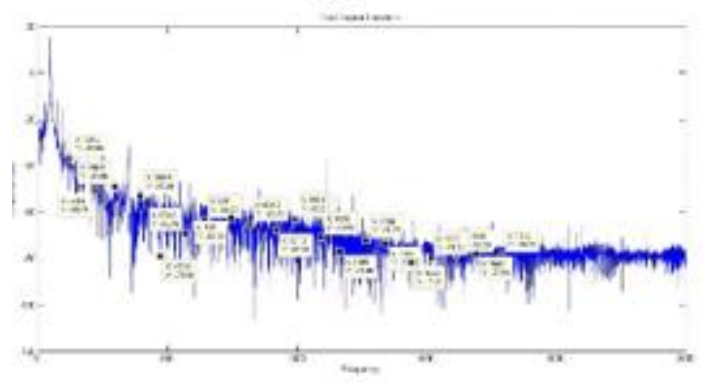

(b)

Figure 3. Bearing normal, a) beban 0\%, b) beban $75 \%$

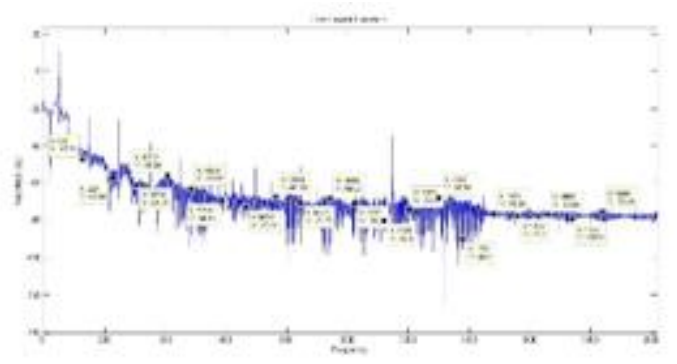

(a)

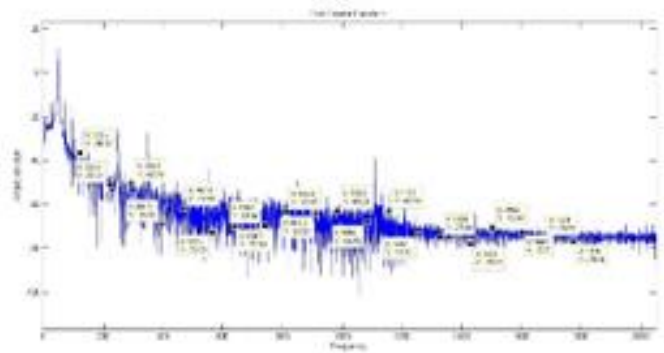

(b)

Figure 4. Kerusakan 1 lubang $2 \mathrm{~mm}$, a) beban $0 \%$, b) beban $75 \%$ 


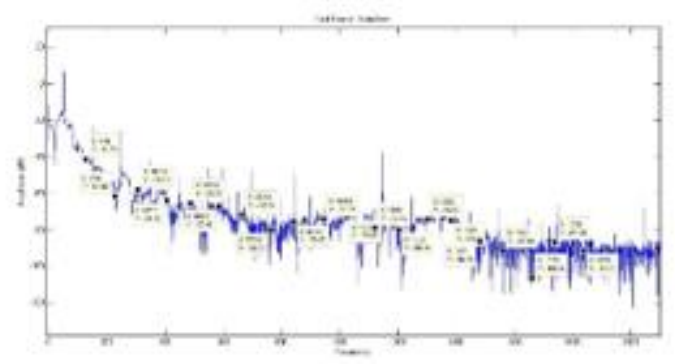

(a)

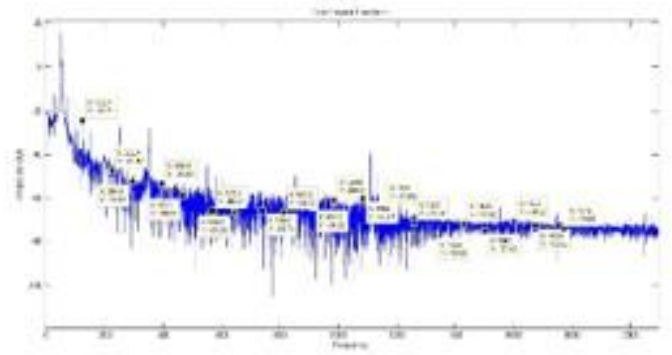

(b)

Figure 5. Kerusakan 2 lubang $2 \mathrm{~mm}$, a) beban $0 \%$, b) beban $75 \%$

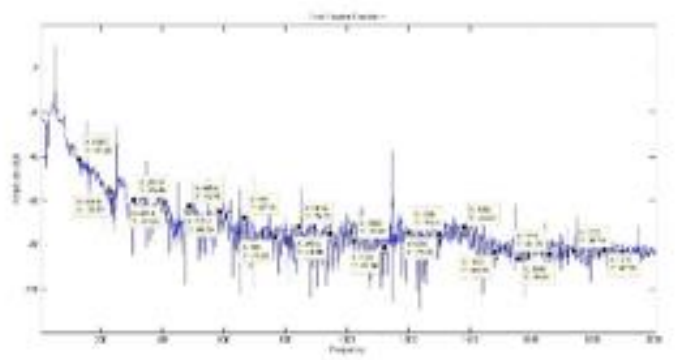

(a)

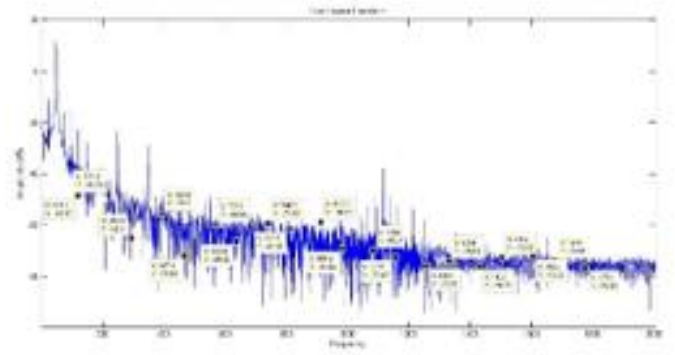

(b)

Figure 6. Kerusakan 2 lubang $2 \mathrm{~mm}$, a) beban $0 \%$, b) beban $75 \%$ 